\title{
Natural gas supply for industrial enterprises in the conditions of the Russian market: current state and development trends
}

\author{
$N V$ Varlamov $^{1}$ and $I A$ Kirshina ${ }^{2, *}$ \\ ${ }^{1}$ Deputy General Director for Engineering, Gazprom Promgaz JSC, Russian Federation, 142702, Moscow region, Vidnoe, Vokzalnaya \\ 23 \\ ${ }^{2}$ Economics Department of Oil and Gas Industry, Gubkin State University of oil and gas, Russian Federation, 119991, Moscow, \\ Leninsky Prospekt 65
}

\begin{abstract}
The article considers the existing problems in natural gas supply for industrial enterprises in the Russian market. The analysis is performed with regards to the use of natural gas in various sectors of economy. Gas consumption in electric power industry and metallurgy is growing at the highest rate. Gasification of the Russian regions leads to the dynamic development of gas distribution system. The use of natural gas in industry makes a significant contribution to the state budget and to the socio-economic situation in the regions.
\end{abstract}

\section{Introduction}

Today, increasing of energy efficiency is a global trend, caused by the constant increase in the cost of energy resources in global energy markets and also driven by the fact that cost of energy resources has a significant share in the cost of final products of the real sector of the economy [1-5].

Gas industry takes significant share in the Russian economy and requires constant development and improvement in order to further increase its efficiency [2-13].

The natural gas supply for industrial enterprises' needs is one of the key areas for the development of the gas industry and is carried out on the basis of systematic approach, involving the coordination of scientific, design, organizational, production and financial measures, with the timing of their implementation and sources of financing.

In general, the Russian gas industry supplies fuel to citizens, industry, electricity and heating plants, and delivers gas for export. The aforementioned gas consumers have various interests, demand fluctuations, and motives for making decisions about switching to gas from alternative fuels, and its unique long-term prospects and level of solvency.

Typically, natural gas is used as a fuel in industry and in everyday life, because it has several advantages, namely:

- Full combustion without soot and smoke;

- $\quad$ No ash is formed after its combustion;

- Ease of ignition and adjustment of the flame size;

- Profitability and ease of transportation to the consumer;

- Absence of harmful products of combustion;
- $\quad$ High efficiency of equipment using fuel;

- Ability to store it in a compressed and liquefied state;

- Production cost for 1 ton of gas in terms of standard fuel is about $10 \%$ comparing to the cost of coal of the same calorific value [2].

Gas is actively used in metallurgical, cement, consumer goods industry, food sectors of the national economy as fuel and as a raw material for the chemical industry [5].

The main objectives of the study are: to analyze the use of natural gas in various industries, identify existing problems in the supply of natural gas to industrial enterprises in the Russian market and consider the prospects for further development of this area.

\section{Methods}

The theoretical basis for this study are the general methodological and scientific principles in research practices, system analysis, including analysis of indicators of the gas supply system development, methods of expert assessments.

The information and empirical base of the study is based on statistics from the Federal State Statistics Service, regional and departmental statistics, and works from leading international authors describing the issues related to the development of gas supply systems and the use of natural gas by industrial enterprises.

\section{Results}

One of the key areas of modernization and innovative technological development in the developed and developing countries is the implementation of energy

\footnotetext{
* Corresponding author: I.kirshina@yandex.ru
} 
saving and energy efficiency mechanisms. Energy conservation and energy efficiency programs are nationwide, and are aimed at energy consumption reduction at all levels of economic activity and for all types of energy resources. One of the most used energy resources consumed all over the world is natural gas, which is the second after electric energy in terms of consumption prevalence [2].

It is possible to conditionally distinguish 4 categories of natural gas consumers in regards to the possible replacement of gas by other primary energy carriers [3].

The first category is industries where the use of gas gives a great economic effect and it is difficult to replace gas with other energy resources. These are municipal consumers and citizens, chemical processing, cracking, conversion, gas pyrolysis, heat treatment of metals.

The second category is ferrous and nonferrous metallurgy, the building materials industry.

The third category is industrial boiler facilities, thermal power plants and state district power stations with units' capacity of less than $100 \mathrm{MW}$.

The fourth category is the industries where it is most easy to replace gas with other primary energy sources. This category includes thermal power plants with units' capacity of more than $100 \mathrm{MW}$, a state district power station with units of high and medium power [3].

In various countries of the world, the growth of natural gas consumption depends on the characteristics of production, the state of the infrastructure and the nature of electricity production [4].

For various sectors of economy gas consumption is divided approximately as follows: $45 \%$ of gas is used in industry; $35 \%$ is used in thermal power plants; $10 \%$ of gas goes to the needs of the housing and municipal consumers [6].

When using gas in power plants, the operating costs associated with storage, preparation and fuel losses are reduced, the power consumption for own needs is reduced, the number of operating personnel is reduced, and capital costs are reduced. [1].

The availability of technological equipment with different temperature conditions at the facilities makes it possible to widely apply the method of integrated use of natural gas. The autonomous combined schemes of using natural gas for the simultaneous generation of thermal and electrical energy attract much interest in industrial energy. In such installations, natural gas is burned in a gas turbine or in internal combustion engine used to drive electric generators. [6].

In the metallurgical industry, gas usage allows one to save expensive coke - up to $15 \%$ ( 1 cubic meter of natural gas replaces $0.9-1.3 \mathrm{~kg}$ of coke), increases the furnace productivity, improves the quality of cast iron, reduces its cost. In the furnace, the use of gas reduces the consumption of coke in a half [1]. The direct reduction of iron method is also based on the use of gas fuel. The use of gas for metalworks increases furnace efficiency in almost 2 times, and the heating time of component parts is reduced by $40 \%$. The use of gas in metallurgy, in addition, extends the service life of the lining. It also reduces the amount of sulfur in the cast iron.
The mechanical industry is also one of the major consumers of natural gas. In the fuel balance of the mechanical industry, the share of combustible gas accounts for about $40 \%$. Enterprises in this industry have a diverse structure of energy consumption.

In metallurgy and mechanical industry, natural gas is also used for heating, rolling, forging, thermal and smelting furnaces.

The cost of cement is reduced by $20-25 \%$. In brick production, the cycle is reduced by $20 \%$, and labor productivity increases by $40 \%$.

In the petrochemical industry, natural gas is used not only as a fuel, but also as a valuable raw material for the production of ammonia, methanol, acetylene, nitrogenous fertilizers, aromatic hydrocarbons and a wide range of chemical intermediates.

A large group in gas consumption is the commercialhousehold sector. High calorie content, ease of use and purity of combustion makes gas an attractive source of energy for cooking and heating homes, offices, etc. [4].

\section{Conclusion}

Since the implementation of gasification programs and the reconstruction of gas distribution and consumption systems requires the investment of large financial resources, an important task remains to optimize the development of territorial gas distribution systems both in terms of gasification and reconstruction priority and order of facility selection for inclusion in these programs, and in terms of structure for funding programs.

In 2018 in the Russian Federation the volume of gas supply for citizens and municipal needs increased by $4.3 \%$, the supplies increased by $9.5 \%$ for electric power industry, by $13 \%$ for agrochemistry and by $18.5 \%$ for metallurgy [14].

In general, the Russian economy is the most gasoriented economy in the world. Unlike other developed countries, gas in Russia is spent mainly by the enterprises of the electric power industry, the metallurgical and chemical industries. In the future, share of electrical power and utility sector in gas consumption can be maintained at $77-78 \%$, the industrial use is able to grow up to $11-12 \%$, and up to $3 \%$ as the motor fuel [12].

There are a number of significant issues regarding the natural gas supply for industrial enterprises in the Russian market:

1. Gas in industry is still underused, it is necessary to use gas more intensively because of environmental problems, especially in depressed industrial regions.

2. Unavailability of transportation and use of gas in some industrial regions (e.g., gold mining in Magadan is non-gasified).

3. Limitation for the gasification of industry may be caused by the reluctance of small industrial enterprises to invest their own funds in re-equipment. Since the increase in the share of gas in the fuel and energy balance plan of the Russian Federation is of 
national importance [15], the problem can be solved by preferential loans, subsidies and tax preferences for medium and small businesses that have the potential to participate in gasification.

Since the Russian gas industry provides natural gas to the chemical, metallurgical, food industry, mechanical engineering, etc., it also influences the transport, agriculture, power supply and utility areas. The use of natural gas in industry provides jobs for hundreds of thousands people in the regions of the country. Gas industry is a significant contributor to the state budget and to the social and economic situation in the regions, by improving the quality of life and improving the ecological situation in the country

\section{References}

1. A.P. Dzyubaa, I.A. Soloveva, Prices-dependent managing the costs of natural gas consumption by industrial enterprises https://cyberleninka.ru/article/n/tsenozavisimoeupravlenie-zatratami-na-potreblenie-prirodnogogaza-promyshlennymi-predpriyatiyami

2. A.P. Dzyubaa, I.A. Soloveva, Short-term forecasting of the parameters of natural gas consumption as an element of price-dependent management of energy costs in industrial enterprises https:/cyberleninka.ru/article/n/kratkosrochnoeprognozirovanie-parametrov-potrebleniyaprirodnogo-gaza-kak-element-tsenozavisimogoupravleniya-energozatratami-na

3. Yu. A. Fertikova, Trends in the development of the gas industry in modern Russia, Actual problems of economics and management: materials of the Intern. Scientific conf., Moscow, April 2011, 87-89 (2011)

4. Gas usage in industries http://biofile.ru/geo/15158.html

5. N. P. Konovalenko, Russia's gas industry: current state and main development trends, Economy: yesterday, today, tomorrow, Volume 6, 10A, 83-94 (2016)

6. Gas in industry Gas profession, LLC Gazprom Dobycha Yamburg (2014) http://gaz-prof.ru/gasaround/gas-industry/

7. The "Gabric production" https://greenologia.ru/eko-problemy/dobycha-gaza

8. Gas engine fuel is becoming increasingly popular in Russia, Gazprom Gazomotornoe Fuel http://gazprom-gmt.ru/press-

center/news/Gazomotornoe_toplivo_stanovitsya_vs e_bolee_populyarnyim_v_Rossii

9. Economic efficiency assessment of transition to compiled natural gas as the fuel for vehicles https://studbooks.net/1588345/tehnika/sfery_ispolz ovaniya_prirodnogo_gaza

10. V.A. Sarkisyan, "Economic Problems of Gas Use in Russia”, Russian Academy of Sciences, Institute of Economic Forecasting - Open Seminar "Economic Problems of the Energy Complex" Sixteenth meeting,

(2000)
https://docplayer.com/44731096-Ekonomicheskieproblemy- ispolzovaniya-gaza-v-rossii.html

11. N. V. Varlamov, I.V. Tverskoy, A.V. Belinsky, Report "The assessment performed by Gazprom Promgaz with regards to the state of development of regions gasification in the Russian Federation as of 01/01/2018

12. Technical certificate of the gas industry in the Russian Federation (as of January 1, 2018)

13. Z.M. Batymurzaeva, Modern situation in gas industry in Russia on the example of Gazprom, Dagestan state university of national economy. URL: https://docplayer.ru/138648085Sovremennoe-sostoyanie-gazovoypromyshlennosti-rf-na-primere-pao-gazprom.html

14. G. Sukhov, S. Gustov, Gas supply to the domestic market. Implementation of the gasification program in regions, Report at the press conference of PJSC "Gazprom, "Gazprom Mezhregiongaz", St. Petersburg, May 22, 2019 http://www.gazprom.ru/f/posts/11/457037/presentat ion-press-conf-2019-05-22-ru_1.pdf

15. Meeting with the head of Gazprom, Alexey Miller, The Chairman of the Board of PJSC Gazprom informed the President about the Company performance in 2018 and about the plans for 2019, Kremlin URL: http: //kremlin.ru/events/president/news/60052 